\title{
Use of Prebiotics and Probiotics of Bacterial and Yeast Origin for Free-Range Broiler Chickens*
}

Author(s)

Pelícia $K^{1}$

Mendes $\mathrm{AA}^{2}$

Saldanha $\mathrm{ESPB}^{3}$

Pizzolante $\mathrm{CC}^{3}$

Takahashi SE ${ }^{1}$

Moreira $J^{1}$

Garcia RG

Quinteiro RR'

Paz ICLA 1

Komiyama $\mathrm{CM}^{1}$

Graduate student, Animal Science, Faculdade de Medicina Veterinária e Zootecnia, UNESP, Campus de Botucatu.

2 Professor, Departamento de Produção e Exploração Animal, Faculdade de Medicina Veterinária e Zootecnia UNESP, Campus de Botucatu.

3 Researcher, Agência Paulista de Tecnologia dos Agronegócios de Brotas, SP.

\section{Mail Address}

Kleber Pelícia

Faculdade de Medicina Veterinária e Zootecnia Unesp - Campus de Botucatu

Fazenda Experimental Lageado, s/n

18.610-490 - Botucatu, SP

Tel: $+55+14 \quad 3811-7189$

E-mail: kleber@fca.unesp.br

\section{Keywords}

Free-range broiler chickens, digestive system, probiotics, symbiotics, yeast.

* Study funded by EMBRAPA (Concórdia, SC, Brazil).

\section{ABSTRACT}

This study aimed to evaluate the effects of probiotics and prebiotics of bacterial and yeast origin on the performance, development of the digestive system, carcass yield and meat quality of free-range broiler chickens.

Five hundred and sixty male chicks of the strain ISA S757-N were reared from one to 84 days old. The birds were distributed in four treatments according to a completely randomized block design: $\mathrm{T} 1=$ Control, $\mathrm{T} 2=$ Probiotics and Prebiotics of bacterial origin, $\mathrm{T} 3=$ Probiotics and prebiotics of yeast origin, $\mathrm{T} 4=$ Probiotics and prebiotics of bacterial origin + probiotics and prebiotics of yeast origin. There were four repetitions with 35 birds per repetition, and the birds had access to a pasture area after 35 days of age. Characteristics evaluated were performance, development of the digestive system, carcass and parts yield, abdominal fat, breast meat physical measurements (length, width and height) and meat quality parameters ( $\mathrm{pH}$ from breast and leg meat, cooking loss and shearing force from breast meat).

Lower mortality $(p<0.05)$ and higher weight gain from 64 to 77 and 64 to 84 days of age were seen in birds supplemented with probiotics and prebiotics of bacterial origin compared to the non-supplemented birds (control). There were significant differences $(p<0.05)$ among treatments for carcass yield. Birds supplemented with both probiotics and prebiotics of microbial and yeast origin (T4) showed higher carcass yield than control birds. Supplementation with probiotics and prebiotics of bacterial origin (T2) or the supplementation of these together with those of yeast origin (T4) reduced mortality and increased the carcass yield in free-range broiler chickens.

\section{INTRODUCTION}

The criteria for the production of organic foodstuffs in Brazil are described by two regulations issued by Ministério da Agricultura (Ministry of Agriculture; Brasil, 1999): Portaria MA No 505 from 16/10/1998 and Instrução Normativa N ${ }^{\circ} 007$ from 17/05/1999. Furthermore, regulations for free-range broiler chikens production are in the Oficio Circular $\mathrm{N}^{\circ}$ 007 from 19/05/99 (Brasil, 1999). Specific strains must be used and diets should not contain ingredients of animal origin, chemical growth promoters and coccidiostats. Birds must be inside poultry houses up to 28 days of age and afterwards should have access to a pasture area with at least $3 \mathrm{~m}^{2}$ per bird. The rearing period should be of at least 85 days.

The association of probiotics and prebiotics is an alternative for the use of chemical additives in the production of free-range broiler chickens. Probiotics are "food supplements that act as growth promoters" according to Fuller (1989), and they compete with pathogenic bacteria in the colonization of the intestinal environment (Vanbelle et al., 1990; 
Pelícia K, Mendes AA, Saldanha ESPB, Pizzolante CC, Takahashi SE, Moreira J, Garcia RG, Quinteiro RR, Paz ICLA, Komiyama CM
Use of Prebiotics and Probiotics of Bacterial and Yeast Origin for Free-Range Broiler Chickens
Silva, 2000). Prebiotics are defined as non-digestible food ingredients such as carbohydrates, peptides, lipids, proteins, oligosaccharides and polysaccharides, that are favorable to a limited number of beneficial bacteria or probiotics (Bradley \& Savage, 1994; Gibson \& Roberfroid, 1995; Andreatti Filho \& Sampaio, 1999).

The naked-neck free-range broiler chickens from the strain ISA S 757-N carries the gene $N a$, and therefore birds from such strain lack feathers, mainly in the region of the neck (Cahaner et al., 1987; Mérat, 1990).

There are few studies that report the effects of probiotics and prebiotics on the production parameters and meat quality of free-range chickens. Therefore, the present study evaluated the use of different probiotics associated to prebiotics on the performance parameters, development of the digestive system, carcass and part yields and meat quality characteristics of free-range broiler chickens.

\section{MATERIAL AND METHODS}

This experiment lasted 84 days and was conducted at the Research and Development Unity of Agência Paulista dos Agronegócios (DDD-APTA-SAA), Brotas, SP, Brazil, from July to September 2003. One-day-old male free-range broiler chickens from the strain ISA S757-N Label Rouge were used. Five hundred and sixty birds were distributed in two poultry houses according to a completely randomized block design. There were four treatments $(\mathrm{T} 1=$ Control, $\mathrm{T} 2=$ Probiotics and prebiotics of bacterial origin, $\mathrm{T} 3=$ Probiotics and prebiotics of yeast origin, and $\mathrm{T} 4=$ Probiotics and prebiotics of bacterial and yeast origin), and four replicates with 35 birds each. The birds had access to open areas after 35 days of age. The probiotics and prebiotics of bacterial origin were, respectively, the commercial products "Colostrum avis", given at the first day of age ( $2 \mathrm{~g}$ per bird), and "Simbiotico plus", given from 1 to 77 days of age ( $2 \mathrm{~kg}$ per ton feed). The compounds contained $10^{6}$ CFU of Enterococcus sp per gram (probiotics) and $85 \%$ of mannanoligosaccharides obtained from the cellular wall of Saccharomyces cerevisiae (prebiotics). The probiotics of yeast origin associated with the prebiotics present on the cell wall of such yeast was provided by the commercial product "Levucell SB 20", given from 1 to 77 days of age at $100 \mathrm{~g} /$ ton diet. It contains $2 \times 10^{10} \mathrm{CFU} / \mathrm{g}$ of Saccharomyces cerevisiae (probiotics and prebiotics).

Diets were given ad libitum and nutritional levels are in accordance with the requirements for the strain in each of the phases (Table 1). Birds were weighed at the beginning of each phase, from 1 to 35,36 to 63 , and 64 to 84 days of age. Mortality was recorded daily and percentages were transformed before statistical analysis using the formula (Steel \& Torrie, 1980):

$$
\sqrt{x+0.5}
$$

\begin{tabular}{|c|c|c|c|}
\hline \multirow[t]{2}{*}{ Ingredient } & \multicolumn{3}{|c|}{ Days } \\
\hline & $1-35$ & $36-63$ & $64-84$ \\
\hline Corn & 61.117 & 66.770 & 73.020 \\
\hline Soybean meal & 34.547 & 29.084 & 23.494 \\
\hline Bicalcium phosphate & 1.869 & 1.738 & 1.497 \\
\hline Limestone & 1.062 & 1.187 & 1.254 \\
\hline Soybean oil & 0.763 & 0.572 & 0.100 \\
\hline Sodium chloride & 0.350 & 0.350 & 0.350 \\
\hline Methionine & 0.093 & 0.099 & 0.084 \\
\hline Vitamin supplement* & 0.100 & 0.100 & 0.100 \\
\hline Mineral supplement** & 0.100 & 0.100 & 0.100 \\
\hline Total & 100.00 & 100.00 & 100.00 \\
\hline \multicolumn{4}{|c|}{ Calculated analysis } \\
\hline ME kcal/kg & 2,900 & 2,950 & 3,000 \\
\hline CP \% & 21.0 & 19.0 & 17.0 \\
\hline Сa \% & 1.0 & 1.0 & 0.950 \\
\hline Available phosphorus\% & 0.46 & 0.43 & 0.380 \\
\hline Lysine \% & 1.05 & 0.93 & 0.800 \\
\hline Methionine \% & 0.42 & 0.40 & 0.360 \\
\hline Met + Cist $\%$ & 0.735 & 0.685 & 0.618 \\
\hline \multicolumn{4}{|c|}{ 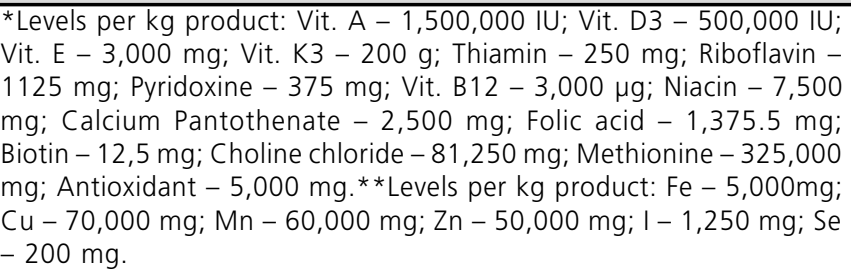 } \\
\hline
\end{tabular}

At 85 days old, five birds were randomly taken from each experimental parcel to evaluate the digestive system, yield of carcass and parts, and breast meat quality. The 80 birds were fasted for 12 hours and slaughtered at the experimental slaughterhouse of FMVZ/UNESP, Botucatu, SP, Brazil. After evisceration, the components of the digestive system were separated. The proventriculus, gizzard, liver, pancreas, duodenum, jejunum and ileum were weighed, and the length of the duodenum, jejunum and ileum was recorded. Besides, the yield of carcass and parts (breast with and without bone and skin; thigh and drumstick with and without bone and skin; wings and back) and abdominal fat were evaluated. The carcass yield, abdominal fat and organs of the digestive system were expressed as percentage of the live weight (weight* 
Pelícia K, Mendes AA, Saldanha ESPB, Pizzolante CC, Takahashi SE, Moreira J, Garcia RG, Quinteiro RR, Paz ICLA, Komiyama CM 100)/live weight). Parts were expressed as percentages of the carcass (part weight*100/carcass weight).

Yield data were evaluated according to Mendes (1990). Percentage data $(x)$ were transformed to arc sen $(x / 100)^{1 / 2}$ previously to the statistical analysis (Steel \& Torrie, 1980).

Meat quality analysis was also performed. The length, width and height of the breast meat were evaluated, besides the $\mathrm{pH}$ of breast and leg meat, cooking loss and shearing force of the breast meat.

The $\mathrm{pH}$ of the breast and leg meat was measured 24 hours post mortem with a pointed-tip electrode (Model 1001, SENTRON) coupled to a LanceFET probe (Model 1074-001, SENTRON). In order to perform physical evaluations of the breast meat, the pectoralis major muscles were dissected, weighed and measured (length, width and height). Measurements were carried out with a pachymeter and the height was measured at the thickest part of the breast. Cooking loss was evaluated in the fillet taken from the left side of each breast. Fillets were weighed, wraped with aluminium foil and both sides were cooked on a grill at an internal temperature of approximately $82{ }^{\circ} \mathrm{C}$. After cooking, the fillets were placed onto an absorbent paper, left at room temperature until their temperature was approximately $25^{\circ} \mathrm{C}$ and re-weighed. The cooking loss was calculated as the difference between the raw and the cooked fillets (Honikel, 1987).

The shearing force was evaluated in the samples used for cooking loss assessment. Cubic samples $(2 \times 2 \times 1.13 \mathrm{~cm})$ were cut with the fibers placed perpendicularly to the Warner-Bratzler device according to Froning et al. (1978).
Use of Prebiotics and Probiotics of Bacterial and Yeast Origin for Free-Range Broiler Chickens
Statistical analysis were carried out using the GLM procedure of SAS (2000).

\section{RESULTS AND DISCUSSION}

During the experimental period, mean ambient temperature was $20.27^{\circ} \mathrm{C} \pm 0.142$, with a minimum temperature of $14.69^{\circ} \mathrm{C} \pm 0.103$ and maximum temperature of $27.22{ }^{\circ} \mathrm{C} \pm 0.179$.

Performance data (live weight, weight gain, feed intake, feed conversion and mortality) are shown in Tables 2 and 3.

The treatments had no effect $(p>0.05)$ on the evaluated performance parameters, except for mortality in the initial phase (1 to 35 days). Afterwards, there was no mortality recorded until the end of the experiment. Birds supplemented with bacterial probiotics and prebiotics showed lower mortality than the non-supplemented birds, but there was no difference ( $p>0.05)$ compared to the other treatments. The difference was seen in the first rearing phase, a phase in which the birds are more sensitive. Indeed, the naked neck strain used in this study has shown low mortality indexes, as reported by Takahashi et al. (2004), who described lower mortality for the naked neck strain when many free-range broiler chickens and conventional strains were compared in confinement and semi-confinement conditions. They also reported concentration of mortality in the initial phase.

Performance results in the present study corroborate findings reported by Dionizio et al. (2002), who observed no effects of the addition of different prebiotic sources in broiler diets on the weight gain,

Table 2 - Performance of free-range broiler chickens in different rearing phases (1-35, 36-63, 1-63 d) supplemented with different additives in the diet.

\begin{tabular}{|c|c|c|c|c|c|c|}
\hline Days & Treatment & Live weight (g) & Weight gain (g) & Food intake (g) & Feed conversion & Mortality (\%) \\
\hline \multirow{5}{*}{$1-35$} & T1 & 823 & 780 & 1,426 & 1.83 & $8.51 \mathrm{a}$ \\
\hline & $\mathrm{T} 2$ & 819 & 776 & 1,499 & 1.93 & $2.23 \mathrm{~b}$ \\
\hline & T3 & 810 & 766 & 1,383 & 1.81 & $5.50 a b$ \\
\hline & $\mathrm{T} 4$ & 832 & 782 & 1,481 & 1.89 & $4.88 a b$ \\
\hline & $C V(\%)$ & 2.6 & 2.6 & 8.6 & 7.4 & 28.5 \\
\hline \multirow{5}{*}{$36-63$} & T1 & 1,960 & 1,137 & 3,172 & 2.79 & 0 \\
\hline & $\mathrm{T} 2$ & 2,008 & 1,189 & 3,166 & 2.66 & 0 \\
\hline & T3 & 1,992 & 1,182 & 3,219 & 2.72 & 0 \\
\hline & $\mathrm{T} 4$ & 1,957 & 1,125 & 3,172 & 2.82 & 0 \\
\hline & $C V(\%)$ & 2.5 & 3.5 & 4.1 & 4.1 & 37.4 \\
\hline \multirow{5}{*}{$221-63$} & T1 & 1,960 & 1,916 & 4,598 & 2.40 & $8.51 \mathrm{a}$ \\
\hline & $\mathrm{T} 2$ & 2,008 & 1,965 & 4,665 & 2.37 & $2.23 \mathrm{~b}$ \\
\hline & T3 & 1,992 & 1,948 & 4,602 & 2.36 & $5.50 a b$ \\
\hline & $\mathrm{T} 4$ & 1,957 & 1,907 & 4,653 & 2.44 & $4.88 a b$ \\
\hline & CV (\%) & 2.5 & 2.6 & 5.0 & 4.2 & 30.0 \\
\hline
\end{tabular}

Means followed by different letters in the column are different by Tukey's test $(\mathrm{p}<0.05)$. T1 = control, $\mathrm{T} 2=$ probiotics and prebiotics of bacterial origin, $\mathrm{T} 3=$ probiotics and prebiotics of yeast origin, $\mathrm{T} 4=$ probiotics and prebiotics of bacterial origin + probiotics and prebiotics of yeast origin. 
Table 3 - Performance of free-range broiler chickens in the periods of 64-77, 78-84, 64-84 and 1-84days of age supplemented with different additives in the diets.

\begin{tabular}{|c|c|c|c|c|c|c|}
\hline Days & Treatment & Live weight (g) & Weight gain (g) & Food intake (g) & Feed conversion & Mortality (\%) \\
\hline \multirow{5}{*}{$64-77$} & T1 & 2,396 & $437 b$ & 1,866 & 4.27 & 0 \\
\hline & T2 & 2,535 & $527 a$ & 1,967 & 3.73 & 0 \\
\hline & T3 & 2,486 & $494 a b$ & 1,640 & 3.32 & 0 \\
\hline & T4 & 2,466 & $510 a b$ & 1,633 & 3.20 & 0 \\
\hline & CV (\%) & 3.0 & 7.6 & 16.2 & 16.1 & 0 \\
\hline \multirow{5}{*}{ 78-84 } & T1 & 2,567 & 171 & 1,121 & 6.56 & 0 \\
\hline & $\mathrm{T} 2$ & 2,699 & 165 & 1,067 & 6.47 & 0 \\
\hline & T3 & 2,627 & 142 & 1,073 & 7.56 & 0 \\
\hline & T4 & 2,603 & 136 & 1,093 & 8.04 & 0 \\
\hline & CV (\%) & 2.8 & 19.1 & 8.8 & 23.8 & 0 \\
\hline \multirow{5}{*}{$2264-84$} & $\mathrm{~T} 1$ & 2,567 & $607 \mathrm{~b}$ & 2,988 & 4.92 & 0 \\
\hline & $\mathrm{T} 2$ & 2,699 & 692 a & 3,034 & 4.38 & 0 \\
\hline & T3 & 2,627 & $635 a b$ & 2,712 & 4.27 & 0 \\
\hline & T4 & 2,603 & $646 a b$ & 2,726 & 4.22 & 0 \\
\hline & CV $(\%)$ & 2.8 & 6.0 & 12.7 & 13.3 & 0 \\
\hline \multirow{5}{*}{ 21-84(dias) } & T1 & 2,567 & 2,523 & 7,586 & 3.01 & $8.51 \mathrm{a}$ \\
\hline & T2 & 2,699 & 2,656 & 7,699 & 2.90 & $2.23 \mathrm{~b}$ \\
\hline & T3 & 2,627 & 2,584 & 7,314 & 2.83 & $5.50 a b$ \\
\hline & T4 & 2,603 & 2,560 & 7379 & 2.88 & $4.88 \mathrm{ab}$ \\
\hline & CV (\%) & 2.8 & 2.9 & 5.7 & 4.7 & 30.0 \\
\hline
\end{tabular}

Means followed by different letters in the column are different by Tukey's test $(p<0.05)$. T1 = control, T2 = probiotics and prebiotics of bacterial origin, $\mathrm{T} 3=$ probiotics and prebiotics of yeast origin, $\mathrm{T} 4$ = probiotics and prebiotics of bacterial origin + probiotics and prebiotics of yeast origin

feed intake and feed conversion. Similarly, no effects on feed conversion, feed intake and live weight were seen in birds challenged with different salmonellas $(S$. Typhimurium, S. Enteritidis, S. Gallinarum and $S$. Pullorum) and different probiotics sources, although lower mortality was seen in birds fed probiotics compared to the birds fed the control diet without additives (Gusils, 2001). Therefore, it can be assumed that the addition of probiotics in the diets of free-range broiler chickens reduces mortality in comparison to birds that are not fed additive supplements in the diets. This is due to the colonization of the intestinal tract by probiotic bacteria, which confers higher resistance to the birds, according to the mechanism of action of probiotics reported by Andreatti Filho \& Sampaio (1999).

Although no performance differences were seen among treatments, increased weight gain would be expected in chickens fed with mannanoligosaccharidebased prebiotics (MOS), since previous studies reported better development of the intestinal mucosa when such additive was used (Sell, 1996; Blikslager \& Roberts, 1997; Macari \& Maiorka, 2000). As stated by some authors, a better development of the intestinal mucosa results in higher weight gain because less energy is used in order to reduce the effects of cells loss in the intestinal lumen, which is caused by pathogenic bacteria when no prebiotics are used. McBride \& Kelly (1990), estimated that the maintenance of the intestinal epithelium and other supporting structures consume $20 \%$ of the crude energy ingested by the animal. Therefore, part of the ingested energy in chickens is destined to the mucosa maintenance, and a greater need of mucosa repair will result in less available energy for weight gain. In the present study, in the later phases, and more specifically, in the periods from 64 to 77 and 64 to 84 days of age, the addition of bacterial probiotics and prebiotics increased weight gain $(p<0.05)$ compared to the control group. Although no differences ( $p>0.05)$ were seen compared to the control group, the other treatments showed numerically higher weight gain from 1 to 84 days. Ofinade \& Babatunde (1996), observed higher weight gain in broilers supplemented with yeast-based probiotics and prebiotics.

The development data of the digestive system (liver, proventriculus, gizzard, pancreas, duodenum, jejunum, ileum and cecum) are shown in Table 4 . There were no differences ( $p>0.05)$ among treatments on the evaluated parameters. The addition of probiotics and prebiotics of different origins had no effect on the parts of the digestive tract probably because the intestinal microflora is balanced, and thus the different additives are not expressed in such situation.

A study with chemical growth promoters and biological growth promoters (prebiotics associated with probiotics) in the diet of free-range broiler chickens reared in semi-confinement and confinement has also 
Pelícia K, Mendes AA, Saldanha ESPB, Pizzolante CC, Takahashi SE, Moreira J, Garcia RG, Quinteiro RR, Paz ICLA, Komiyama CM
Use of Prebiotics and Probiotics of Bacterial and Yeast Origin for Free-Range Broiler Chickens not shown effects on the intestine length, but there was higher intestine percentage (Pelícia, 2004). On the other hand, Sato et al. (2002) did not observe effects of probiotics addition to the diet of broilers on the percentage and length of the intestine. Birds fed probiotics and prebiotics in the diet and challenged with Salmonella Enteritidis had also no differences in the length and percentage of cecum, duodenum and jejunum (Takahashi et al., 2004). The addition of probiotics in the diets of broilers had no effect on the percentages of liver and pancreas, although higher gizzard percentage was seen (Loddi et al., 2000).

Table 4 - Development of the components of the digestive system in free-range broiler chickens supplemented with different additives in the diet from 1 to 84 days of age.

\begin{tabular}{lrrrrl} 
Variables & \multicolumn{4}{c}{ Treatments } & \multirow{2}{*}{ CV(\%) } \\
\cline { 2 - 5 } & T1 & T2 & T3 & T4 & \\
Proventriculus (\%) & 0.31 & 0.31 & 0.30 & 0.31 & 13.24 \\
Gizzard (\%) & 2.08 & 1.88 & 1.90 & 1.78 & 13.49 \\
Liver (\%) & 1.58 & 1.51 & 1.58 & 1.57 & 7.74 \\
Pancreas (\%) & 0.18 & 0.16 & 0.17 & 0.17 & 13.49 \\
Duodenum (\%) & 0.45 & 0.43 & 0.54 & 0.47 & 15.84 \\
Duodenum (cm) & 24.50 & 24.12 & 24.75 & 25.3 & 8.69 \\
Jejunum (\%) & 0.90 & 0.86 & 0.87 & 0.92 & 16.88 \\
Jejunum (cm) & 57.84 & 56.92 & 52.63 & 57.08 & 8.94 \\
lleum (\%) & 0.86 & 0.72 & 0.74 & 0.84 & 10.75 \\
lleum (cm) & 57.08 & 57.42 & 57.29 & 56.75 & 9.24 \\
Cecum (\%) & 0.77 & 0.76 & 0.71 & 0.74 & 11.30 \\
Cecum (cm) & 44.58 & 41.92 & 42.63 & 43.17 & 6.32 \\
\hline T1 = control, T2 = probiotics and prebiotics of bacterial origin, T3= \\
probiotics and prebiotics of yeast origin, T4 = probiotics and prebiotics \\
of bacterial origin + probiotics and prebiotics of yeast origin.
\end{tabular}

Yield results of the carcass and parts (breast, breast meat, leg, leg meat, wings and back) and abdominal fat results are shown in Table 5. Birds fed both bacterialand yeast-based probiotics and prebiotics (T4) had higher carcass yield $(p<0.05)$ compared to the control group. No effects $(p>0.05)$ of treatments were seen on the yields of breast, breast meat, leg, leg meat, wings and back. Although there were differences among treatments for the carcass yield, this finding was not expected and must be better investigated, since the birds showed no differences in performance, digestive system parameters and other factors that could explain such result. These results are different from a previous study in which probiotics were added to the diet of broilers and had no effect on the carcass, leg and breast yields (Maiorka et al., 2001). Dionizio et al. (2002) also evaluated different prebiotic sources in broiler diets and reported no effects on carcass and breast yield. Pelícia (2004) evaluated chemical additives and probiotics associated to prebiotics in the diet of free-range broiler chickens reared in two different rearing systems (confined and semi-confined) and reported no effects on the carcass and part yields (breast, breast meat, leg, breast meat, wings and back).

Abdominal fat percentage was not affected ( $p>0.05$ ) by the addition of probiotics and prebiotics. Such finding corroborates previous findings reported for broilers (Loddi et al., 2000; Dionizio et al., 2002) and free-range broiler chickens reared in two different systems, confined and semi-confined (Pelicia, 2004).

A possible explanation for the abdominal fat and parts yield results from the present study and other previously reported results is that there were no unbalance in the intestinal microflora and that the different chemical and biological promoters are similar in the control of the intestinal flora in the digestive tract. Once parasites injure the digestive tract, feed efficiency is directly affected and, consequently, there is a decrease in meat transformation and fat deposition.

Table $\mathbf{5}$ - Carcass and part yields, abdominal fat, physical measurements of the breast meat (length, width and height) and characteristics of meat quality ( $\mathrm{pH}$ of breast and leg meat, cooking loss and shearing force) of free-range broiler chickens supplemented with different additives in the diet from 1 to 84 days of age.

\begin{tabular}{|c|c|c|c|c|c|}
\hline \multirow[t]{2}{*}{ Variables } & \multicolumn{4}{|c|}{ Treatments } & \multirow[t]{2}{*}{ CV(\%) } \\
\hline & T1 & $\mathrm{T} 2$ & T3 & T4 & \\
\hline Carcass (\%) & $67.49 \mathrm{~b}$ & $68.16 \mathrm{ab}$ & $67.92 \mathrm{ab}$ & $69.01 \mathrm{a}$ & a 2.56 \\
\hline Breast (\%) & 28.72 & 29.74 & 29.76 & 28.88 & 5.33 \\
\hline $\operatorname{Leg}(\%)$ & 33.26 & 32.56 & 32.25 & 33.08 & 4.02 \\
\hline Breast meat (\%) & 19.47 & 19.94 & 20.36 & 19.58 & 6.77 \\
\hline Leg meat $(\%)$ & 21.47 & 20.80 & 21.08 & 21.46 & 4.99 \\
\hline Back (\%) & 24.69 & 24.47 & 25.07 & 24.84 & 5.39 \\
\hline Wings (\%) & 13.34 & 13.44 & 13.57 & 13.42 & 6.87 \\
\hline Abdominal fat (\%) & 1.63 & 1.59 & 1.99 & 1.78 & 21.31 \\
\hline Breast length (cm) & 16.96 & 17.64 & 17.56 & 17.41 & 5.50 \\
\hline Breast width $(\mathrm{cm})$ & 14.75 & 14.78 & 14.75 & 14.54 & 7.33 \\
\hline Breast height $(\mathrm{cm})$ & 2.09 & 2.15 & 2.12 & 2.07 & 10.59 \\
\hline Breast meat $\mathrm{pH}$ & 5.74 & 5.71 & 5.73 & 5.76 & 2.15 \\
\hline Leg meat $\mathrm{pH}$ & 6.01 & 5.95 & 5.98 & 5.95 & 2.08 \\
\hline Cooking loss (g) & 19.49 & 20.12 & 20.86 & 20.39 & 19.66 \\
\hline Shearing force $(\mathrm{kgf} / \mathrm{kg})$ & 1.80 & 2.14 & 1.92 & 1.97 & 25.44 \\
\hline \multicolumn{6}{|c|}{$\begin{array}{l}\text { Means followed by different letters in the line are different by Tukey's } \\
\text { test }(p<0.05) . T 1=\text { control, } T 2=\text { probiotics and prebiotics of bacterial } \\
\text { origin, } T 3=\text { probiotics and prebiotics of yeast origin, } T 4=\text { probiotics } \\
\text { and prebiotics of bacterial origin + probiotics and prebiotics of yeast } \\
\text { origin. }\end{array}$} \\
\hline
\end{tabular}

The physical measurements and quality of meat in free-range broiler chickens are shown in Table 5 . There were no differences ( $p>0.05)$ among treatments for 
Pelícia K, Mendes AA, Saldanha ESPB, Pizzolante CC, Takahashi SE, Moreira J, Garcia RG, Quinteiro RR, Paz ICLA, Komiyama CM
Use of Prebiotics and Probiotics of Bacterial and Yeast Origin for Free-Range Broiler Chickens the evaluated variables. These results are similar to a previous study that evaluated the use of growth promoters of chemical and biological (prebiotics associated to probiotics) origin and two rearing systems (confined and semi-confinement) on the physical measurements and meat quality characteristics in freerange broiler chickens (Pelícia, 2004). A similar rationale as the one for yield and abdominal fat can be used, i.e., there was no unbalance of the intestinal microflora. The debilitation of the intestinal system results in poorer feed efficiency, and consequently in lower meat transformation and effects on the physical characteristics of the breast meat. It is known that there is a relationship between nutrients and organism, making it clear that the poorer feed efficiency is related to a lower nutrient absorption. Therefore, it can also have influence on the meat qualitative characteristics, since the nutrient balance is directly related to the normal physiological funtions in birds.

\section{CONCLUSIONS}

The use of probiotics and prebiotics of bacterial origin or the association with probiotics and prebiotics of yeast origin are alternatives for free-range broiler chickens, since they not only reduce mortality indexes but also increase carcass yield.

Further studies about the use of probiotics and prebiotics should be performed and should include microorganism counts in the digestive tract, because some studies reported that the balance of the intestinal microflora is reflected in better usage of the diet by the birds, which consequently affects the performance indexes.

\section{REFERENCES}

Andreatti Filho RL, Sampaio HM. Probióticos e prebióticos realidade na avicultura industrial moderna. Revista de Educação Continuada do CRMV 1999; 2(3):59-71.

Blikslager AT, Roberts C. Mechanisms of intestinal mucosa repair. Journal of the American Veterinary Medical Association 1997; 211(11):1437-41.

Bradley GT, Savage TF. Enhanced utilization of dietary calcium, phosphorus, nitrogen and metabolizable energy in poults fed diets containing a yeast culture. Poultry Science 1994; 73 (Suppl 1): 125.

Brasil. Ministério da Agricultura e do Abastecimento. Ofício Circular DOI/DIPOA N007/99, 19th May 1999. Brasília, DF.

Cahaner A, Dunnington EA, Jones DE. Evaluation of two commercial broiler male lines differing in efficiency of feed utilization. Poultry
Science 1987; 66(7):1101-10

Dionízio MA, Bertechini AG, Kato RK. Prebióticos como promotores de crescimento para frangos de corte - desempenho e rendimento de carcaça. Ciência e Agrotecnologia 2002; 26(Edição Especial): 1580-87

Froning GW, Babji AS, Mather FB. The effect of presslaughter temperatures, stress, struggle and anesthetization on color and textural characteristics of turkey muscle. Poultry Science 1978; 57 (3):630-3.

Fuller R. Probiotics in man and animals: a review. Journal of Applied Bacteriology 1989; 66:365-78.

Gibson GR, Roberfroid MB. Dietary modulation of the human colonic microbiota: introducing the concept of prebiotics. Journal of Nutrition 1995; 125(6):1401-12

Gusils C. Alimentación probiótica para pollos. In: $38^{\circ}$ Congresso Latino Americano de Avicultura; 2001. Guatemala, Guatemala. p. 625-31.

Honikel KO. The water binding of meat. Fleischwirttssch 1987; 67: 1098-1102.

Loddi MM, Gonzales E, Takita TS. Uso de probiótico e antibiótico sobre o desempenho, rendimento e a qualidade de carcaça de frangos de corte. Revista Brasileira de Zootecnia 2000; 29(4):1124 $-31$.

Macari M, Maiorka A. Função gastrintestinal e seu impacto no rendimento avícola. In: $2^{a}$ Conferência Apinco de Ciência e Tecnologia Avícolas; 2000; Campinas, São Paulo. Brasil. p.161-74.

Maiorka A, Santin E, Sugeta SM, Almeida JG, Macari M. Utilização de prebiótico, probiótico ou simbiótico em dietas para frangos. Revista Brasileira de Ciência Avícola 2001; 3(1):75-82.

McBride BW, Kelly JM. Energy cost of absorption and metabolism in the ruminant gastrointestinal tract and liver: a review. Journal of Animal Science 1990; 68(9):2997-3010.

Mendes AA. Efeito de fatores genéticos, nutricionais e de ambiente sobre o rendimento de carcaça de frangos de corte. Tese (Livre Docência). Botucatu (SP): Faculdade de Medicina Veterinária e Zootecnia, Universidade Estadual Paulista, 1990. 103p.

Merat P. Pleiotropic and associated effects of major genes. Poultry Breeding and Genetics 1990; 429-67.

Ofinade AA, Babatunde GM. Supplemental value of dried yeast in a high-fibre diet for broiler chicks. Animal Feed Science and Technology 1996; 62: 91-6.

Pelícia K. Utilização de Probiótico e Prebiótico para Frangos de Corte Tipo Colonial. (Dissertação). Botucatu (SP): Faculdade de Medicina Veterinária e Zootecnia, Universidade Estadual Paulista, 2004. 71p.

SAS Institute. 2000. SAS user's guide. Cary. 1 CD ROM.

Sato RN, Loddi MM, Nakaghi LSO. Uso de antibiótico e/ ou probiótico 
como promotores de crescimento em rações iniciais de frangos. Revista Brasileira de Ciência Avícola 2002; 4(Supplement):37.

Sell JL. Physiological limitations and potential for improvement in gastrointestinal tract function of poultry. Journal Applied Poultry Research 1996; 5:96-101.

Silva EN. Probióticos e prebióticos na alimentação de aves. In: $2^{\text {a }}$ Conferência Apinco de Ciência e Tecnologia Avícolas; 2000; Campinas, São Paulo. Brasil. p. 241-51.

Steel RGD, Torrie JH. Principles and procedures of statistics. New York (NY):Mcgraw-Hill, 1980

Takahashi SE, Mendes AA, Saldanha ESPB, Pizzolante CC, Pelícia K. Eficiência da utilização de prebióticos e probióticos sobre o desempenho, rendimento, qualidade de carne e presença de Salmonella spp na carcaça de frangos de corte tipo colonial. Brazilian Journal of Poultry Science 2004; 6(2):99-104.

Vanbelle M, Teller E, Focant M.Probiotics in animal nutrition: a review. Arch. Tierernahr 1990: 40(7):543-567. 